\title{
Phenobarbitone in Neonatal Jaundice
}

\author{
D. SINNIAH, L. K. TAY, and A. E. DUGDALE \\ From Department of Paediatrics, University of Malaya, Malaysia
}

\begin{abstract}
Sinniah, D., Tay, L. K., and Dugdale, A. E. (1971). Archives of Disease in Childhood, 46, 712. Phenobarbitone in neonatal jaundice. Eighty-three jaundiced newborn infants were studied, 41 received phenobarbitone, and 42 served as controls. 48 hours after starting treatment the mean serum bilirubin level of the group of normal birthweight infants was significantly lower than that of controls. Exchange transfusions were required in 6 of the 32 control cases and in none of the 28 treated cases.

There were no significant differences in the mean serum bilirubin levels or in the exchange transfusion rates between treated and control low birthweight infants.
\end{abstract}

It is recognized that there is a high incidence of hyperbilirubinaemia among newborn infants in this part of the world (Yeung and Field, 1969; Brown and Boon, 1965). Approximately 1 in 70 babies delivered in the University Hospital, Kuala Lumpur, requires an exchange transfusion (Sinniah, 1971). Any measures that will cause a significant reduction in serum bilirubin levels and a decrease in the need for exchange transfusions will be of the greatest importance.

Catz and Yaffe (1968) have shown that phenobarbitone enhances the conjugation and excretion of bilirubin in newborn animals. Crigler and Gold (1966) and Yaffe et al. (1966) have successfully used phenobarbitone to lower the serum bilirubin in cases of the Crigler-Najiar syndrome. Trolle (1968a) and Maurer et al. (1968) have shown that infants born to phenobarbitone-treated mothers have a lower incidence of jaundice. In a second study, Trolle (1968b) showed that infants treated with phenobarbitone had a lower incidence of jaundice but the effect appeared to be less at higher levels of bilirubin.

Yeung and Field (1969) studied the effect of phenobarbitone therapy on jaundiced Chinese newborn infants and found significant reductions of bilirubin levels in 'normal weight' babies but not in the premature babies. Other studies have not shown significant differences in serum bilirubin levels between control infants and infants treated with phenobarbitone either before

Received 10 March 1971. or after the appearance of jaundice (Ramboer, Thompson, and Williams, 1969; McMullin, 1968; Cunningham, Mace, and Peters, 1969).

Because of these conflicting reports, the present study was undertaken to evaluate the effectiveness of postnatal treatment of neonatal hyperbilirubinaemia in term infants and premature infants with phenobarbitone therapy.

\section{Material and Methods}

Babies born in the Maternity Unit, University Hospital, Kuala Lumpur, from the beginning of March to the end of June 1970, were observed daily for jaundice. Those who developed mild clinical jaundice, which was found to correspond to a serum bilirubin level of about $10 \mathrm{mg} / 100 \mathrm{ml}$, had daily estimations of serum bilirubin. Alternate cases received phenobarbitone syrup daily until the serum bilirubin started subsiding or fell below $10 \mathrm{mg} / 100 \mathrm{ml}$. The dosage was $5 \mathrm{mg}$, 8-hourly for normal weight babies (birthweight $>2.5$ $\mathrm{kg}$ ) and $6 \mathrm{mg} / \mathrm{kg}$ per 24 hours in 3 equally divided 8-hourly doses for those under $2.5 \mathrm{~kg}$. The other group of infants not receiving phenobarbitone served as controls.

Serum bilirubins were estimated by the micromodification method of Malloy and Evelyn (1937). They were estimated daily until the peak level was passed and the bilirubin fell towards or under $10 \mathrm{mg} /$ $100 \mathrm{ml}$. Subsequent lower readings and postexchange bilirubin levels were not included in the final analysis. Normal weight babies were analysed as a separate group from low birthweight babies.

(Precision of method used to assess serum bilirubin: serum bilirubin was estimated in duplicate in 9 samples of blood and gave two sets of values which corresponded 
within $\pm 0.52 \mathrm{mg} / 100 \mathrm{ml}$ of each other at the $95 \%$ confidence limit.)

\section{Results}

A total of 83 newborn infants was studied. Race, sex, and weight distribution of these infants are shown in Table $I$.

TABLE I

Race, Sex, and Weight Distribution of Control and Phenobarbitone-treated Infants

\begin{tabular}{l|c|c|c|c|c}
\hline \multirow{2}{*}{ Race } & \multirow{2}{*}{ Sex } & \multicolumn{2}{|c|}{ Birthweight } & $<2.5 \mathrm{~kg}$ & \multicolumn{2}{c|}{ Birthweight } \\
\cline { 3 - 6 } & & $\begin{array}{c}\text { Control } \\
\text { Group }\end{array}$ & $\begin{array}{c}\text { Treated } \\
\text { Group }\end{array}$ & $\begin{array}{c}\text { Control } \\
\text { Group }\end{array}$ & $\begin{array}{c}\text { Treated } \\
\text { Group }\end{array}$ \\
\hline Malay & $\mathrm{M}$ & 1 & 1 & 1 & 5 \\
Chinese & $\mathrm{F}$ & 4 & 2 & 3 & 3 \\
Indian & $\mathrm{M}$ & 2 & 5 & 16 & 9 \\
& $\mathrm{M}$ & - & - & 4 & 10 \\
& $\mathrm{~F}$ & - & - & 6 & 1 \\
\hline \multicolumn{2}{l|}{ Total no. of cases } & 10 & 13 & 32 & 28 \\
\hline
\end{tabular}

Normal weight infants. 28 infants received phenobarbitone and 32 acted as controls. None of the patients had G6PD deficiency or Rh incompatibility. Exchange transfusions were required in 6 of the 32 controls; 2 had exchange transfusions on the second day and 4 on the third day of the study, respectively. Exchange transfusions were not required in any of the infants who received phenobarbitone.

Two methods were used to test the effectiveness of phenobarbitone therapy.

(1) If phenobarbitone had no effect, the proportion of infants requiring exchange transfusion should be the same. As the infants were allocated to control and treatment groups alternately, there were some differences in the internal composition of each group. Before the effect of phenobarbitone could be determined, it must be shown that these internal differences did not themselves affect the number of exchange transfusions.

This was done by using multifactorial analysis of variance, so that the effects of race, sex, weight, and phenobarbitone could be assessed separately. Table II shows a significant reduction in the number of exchange transfusions in infants treated with phenobarbitone. The effects of sex and weight were not significant. The effect of race was at the borderline of significance, but this finding does not reduce the significance of the difference due to phenobarbitone.

The present evidence suggests that treatment with phenobarbitone reduced the need for exchange transfusion in these infants.

\section{TABLE II}

Effect of Race, Sex, Weight, and Phenobarbitone in Need for Exchange Transfusion

\begin{tabular}{l|c|c}
\hline Effect of Factor & Hypothesis & $\begin{array}{c}\text { Probability } \\
\text { of Null } \\
\text { Hypothesis }\end{array}$ \\
\hline Phenobarbitone & $\begin{array}{c}\text { Controls require greater num- } \\
\text { ber of exchange transfusions } \\
\text { Males require greater number } \\
\text { of exchange transfusions } \\
\text { Infants of lower birthweight } \\
\text { require greater number of } \\
\text { exchange transfusions } \\
\text { Non-Chinese infants require } \\
\text { greater number of exchange } \\
\text { transfusions }\end{array}$ & 0.02 \\
\hline Race & 0.27 \\
\hline
\end{tabular}

(2) The second method of determining the effectiveness of treatment with phenobarbitone was to follow the bilirubin levels of matched pairs of infants. Sixteen pairs were matched for race, sex, and weight, and their serum bilirubin levels were compared at time of initial measurement, then at 24, 48, and 72 hears. Table III shows the mean bilirubin levels and the total number of infants who had bilirubin determinations at the different times in the 2 groups. This excludes those infants who either had exchange transfusions or whose bilirubin level had fallen towards or under $10 \mathrm{mg} / 100 \mathrm{ml}$ during the previous 24 hours. The results of statistical analysis are also shown in the same Table.

TABLE III

Serum Bilirubin Levels in Matched Pairs of Infants

\begin{tabular}{|c|c|c|c|c|}
\hline & \multicolumn{4}{|c|}{ Mean Serum Bilirubin Levels $(\mathrm{mg} / 100 \mathrm{ml}) \pm \mathrm{SD}$} \\
\hline & Initial $(16)^{\star}$ & At $24 \mathrm{hr}(16)$ & At $48 \mathrm{hr}(15)$ & At $72 \mathrm{hr}(9)$ \\
\hline $\begin{array}{l}\text { Control group } \\
\text { Treated group } \\
\text { Significance of difference }(P)\end{array}$ & $\begin{array}{l}14 \cdot 6 \pm 2 \cdot 4 \\
14 \cdot 5 \pm 2 \cdot 5 \\
0 \cdot 80\end{array}$ & $\begin{array}{c}14 \cdot 1 \pm 4 \cdot 3 \\
13 \cdot 7 \pm 2 \cdot 9 \\
0 \cdot 70\end{array}$ & $\begin{array}{l}15 \cdot 5 \pm 4 \cdot 2 \\
12 \cdot 6 \pm 1 \cdot 8 \\
0 \cdot 01\end{array}$ & $\begin{array}{l}13 \cdot 0 \pm 2 \cdot 8 \\
13 \cdot 2 \pm 2 \cdot 2 \\
0 \cdot 80\end{array}$ \\
\hline
\end{tabular}

$\star$ Figures in parentheses indicate number of pairs. 
There were no significant differences in the mean bilirubin levels between the control and treated group at the initial estimation or at 24 hours, but highly significant differences were found at 48 hours. There was no significant difference in the levels at $\mathbf{7 2}$ hours, but this cannot reflect meaningfully on the effectiveness of phenobarbitone therapy, as by 72 hours 4 pairs had to be excluded because 4 of the control patients had had exchange transfusions.

Low birthweight infants. Of the 23 low birthweight infants, 13 received phenobarbitone while the other 10 served as controls. The control group ( 3 males and 7 females) comprised 5 Malays and 5 Chinese, while the treated group ( 6 males and 7 females) comprised 3 Malays and 10 Chinese. The mean birthweights of control and treated infants were $2.0 \pm 0.4 \mathrm{~kg}(\mathrm{SD})$ and $2.0 \pm 0.3 \mathrm{~kg}(\mathrm{SD})$, respectively. There were no statistical differences in sex distribution, race distribution, and birthweights between the 2 groups $(0.5>P>0.3$; $0.2>P>0.1 ; 0.6>P>0.5)$. One patient in each of the 2 groups had glucose-6-phosphate dehydrogenase deficiency. Exchange transfusions were required in 3 of the 13 treated cases $(23 \%)$ and in 3 of the 10 control cases (30\%). The exchange transfusions were carried out on the second day of the study in 3 treated cases and 2 controls and on the third day of study in one control. There was no significant difference in the incidence of severe hyperbilirubinaemia between the 2 groups $(0 \cdot 8>P>0 \cdot 7)$.

\section{Discussion}

A recent controlled trial (Levin, McMullin, and Mobarak, 1970) of phenobarbitone in the treatment of neonatal jaundice revealed a small but significant reduction of the mean bilirubin level of treated cases 24 hours after starting treatment. But as there were no significant differences in the mean bilirubin levels of the treated and untreated cases at 48 and 72 hours after starting treatment, and as there was no significant difference in the maximum recorded levels between the 2 groups, it was concluded by the authors that phenobarbitone had no place in the management of established neonatal jaundice.

We have in this study two pieces of evidence suggesting that phenobarbitone is useful in the postnatal treatment of hyperbilirubinaemia in normal weight babies, namely the significant reduction in bilirubin levels in the phenobarbitone treated group, and the reduction in the need for exchange transfusion in this group. The two pieces of evidence complement each other and suggest that phenobarbitone is effective. It was not effective, however, in lowering serum bilirubin levels in low birthweight infants in the dosages used.

These findings are in agreement with those of Yeung and Field (1969) but at variance with others (Ramboer et al., 1969; McMullin, 1968; Cunningham et al., 1969).

It is now recognized that the pattern of neonatal jaundice in this geographical locality is different from that in Western countries. Brown and Boon (1965) found a higher incidence of hyperbilirubinaemia among Asian infants compared to British infants born in Singapore. They postulated that there was an element of liver immaturity in term Malay, Chinese, and Indian infants, and there was a transient depression of hepatic glucuronyltransferase activity in the newborn period, resulting in an increase in the incidence of hyperbilirubinaemia.

It is quite possible that phenobarbitone has a greater enhancing effect on the production of glucuronyl transferase in these infants than in their more 'mature' counterparts in the West, thus accounting for the conflicting data which have been published.

There was no increase in mortality rate in infants treated with phenobarbitone and no serious adverse effects were noted apart from drowsiness and difficulty in feeding which occasionally persisted for as long as 2 days after treatment was discontinued.

There is a high incidence of neonatal hyperbilirubinaemia among Malay, Chinese, and Indian newborn infants delivered in this hospital. Approximately 1 in 70 newborns require exchange transfusion (Sinniah, 1971). Phenobarbitone has been found to be effective in reducing the serum bilirubin levels of jaundiced normal weight babies and also the need for exchange transfusions. This is an important development for babies in this part of the world.

We wish to express our appreciation to the staff of the Department of Paediatrics, University Hospital, for their help; and Dr. C. G. Beng, and Mr. K. P. Tan for laboratory assistance.

\section{REFERENCES}

Brown, W. R., and Boon, W. H. (1965). Ethnic group differences in plasma bilirubin levels of full-term, healthy Singapore newborns. Pediatrics, 36, 745

Catz, C., and Yaffe, S. J. (1968). Barbiturate enhancement of bilirubin conjugation and excretion in young and adult animals. Pediatric Research, 2, 361.

Crigler, J. F., and Gold, N. I. (1966). Sodium phenobarbitalinduced decrease in serum bilirubin in an infant with congenital nonhaemolytic jaundice and kernicterus. Fournal of Clinical Investigation, 45, 998. 


\section{Phenobarbitone in Neonatal Jaundice}

Cunningham, M. D., Mace, J. W., and Peters, E. R. (1969). Clinical experience with phenobarbitone in icterus neonatorum. Lancet, 1, 550.

Levin, G. E., McMullin, G. P., and Mobarak, A. N. (1970). Controlled trial of phenobarbitone in neonatal jaundice. Archives of Disease in Childhood, 45, 93.

McMullin, G. P. (1968). Phenobarbitone and neonatal jaundice. Lancet, $2,978$.

Malloy, H. T., and Evelyn, K. A. (1937). The determination of bilirubin with the photoelectric colorimeter. Fournal of Biological Chemistry, 118, 481.

Maurer, H. M., Wolff, J. A., Finster, M., Poppers, P. J., Pantuck, E., Kuntzman, R., and Conney, A. H. (1968). Reduction in concentration of total serum-bilirubin in offspring of women treated with phenobarbitone during pregnancy. Lancet, 2, 122.

Ramboer, C., Thompson, R. P. H., and Williams, R. (1969). Controlled trials of phenobarbitone therapy in neonatal jaundice. Lancet, 1, 966.
Sinniah, D. (1971). Neonatal hyperbilirubinaemia. Medical Fournal of Malaya, 25, 211.

Trolle, D. (1968a). Phenobarbitone and neonatal icterus. Lancet, 1, 251.

Trolle, D. (1968b). Decrease of total serum-bilirubin concentration in newborn infants after phenobarbitone treatment. Lancet, 2, 705.

Yaffe, S. J., Levy, G., Matsuzawa, T., and Baliah, T. (1966). Enhancement of glucuronide-conjugating capacity in a hyperbilirubinemic infant due to apparent enzyme induction by phenobarbital. New England Fournal of Medicine, 275, 1461.

Yeung, C. Y., and Field, C. E. (1969). Phenobarbitone therapy in neonatal hyperbilirubinaemia. Lancet, 2, 135.

Correspondence to Dr. D. Sinniah, Department of Paediatrics, University of Malaya, Kuala Lumpur, Malaysia. 